\title{
Exploring the Link Between Competitive Strategies and Organizational Per- formance in Beverage Industry. (A case of Nestle PLC)
}

https://doi.org/10.21272/sec.3(1).116-126.2019

\section{Kowo Solomon Akpoviroro}

$\mathrm{PhD}$, Asisstant Professor, Department of Business and Entrepreneurship, Kwara State University, Malete Nigeria

\section{Akinbola Olufemi Amos}

PhD, Assistant Professor, Department of Business Administration, Federal University of Agriculture, Abeokuta, Nigeria

\section{Akinriola Oladipupo Olalekan}

$\mathrm{PhD}$, Assistant Professor, Department of Accounting, Babcock University Ogun State, Nigeria

\begin{abstract}
This paper summarizes the arguments and counter arguments within the scientific discussion on the issue exploring the link between Competitive Strategies and Organizational Performance in Beverage Industry. Competition is a critical force that shapes the affairs of an organization in a competitive environment and its impact cannot be over emphasized. The main purpose of the research is to examine the significant effect of cost management strategy on sales turnover and focus strategies on market leadership coupled with the significant effect of competitive strategies on organizational performance. Systematization literary sources and approaches for solving the problem are carried out in the following logical sequence. A cross-sectional design was adopted for this study. The field survey was carried out in the year 2018. The study employed statistical tools which include: analysis of variance (ANOVA), correlation efficient and regression analysis in testing hypotheses. Statistical package for the social sciences, (SPSS) was employed. Yamane formula was adopted to determine the sample size. The object of research is the management of Nestle Plc, Lagos Nigeria. 124 copies of questionnaire were administered to the top and middle level management of Nestle Plc Lagos Nigeria to get primary data that treated and tested appropriate research questions and hypotheses accordingly. The paper presents the results of an empirical analysis which showed that there was a significant relationship between cost management strategies and sales turnover and also market focus strategies can lead to improved market leadership and share. The research empirically confirms and theoretically proves that competitive strategies can lead to improved organizational performance.The results of the research would help organization to create a scorecard on which performance can be measured. The study recommends that organizations should consistently seek ways of utilizing the competitive strategies at their disposal as it helps improve organizational performance and ultimately lead to a sustained competitive advantage over competitors.
\end{abstract}

Keywords: cost management strategy, focus strategy, organizational performance, competitive strategies. JEL Classification: M1, M11.

Cite as: Akpoviroro, Kowo Solomon, Amos, Akinbola Olufemi, Olalekan, Akinrinola (2019). Exploring the Link Between Competitive Strategies and Organizational Performance in Beverage Industry. (A case of Nestle PLC). SocioEconomic Challenges, 3(1), 116-126. https://doi.org/10.21272/sec.3(1).116-126.2019.

(C) The Authors, 2019. This article is published with open access at Sumy State University.

\section{Introduction}

Salarou (2015) Posit that Organizations exist in challenging economic environments that is highly dynamic in nature as regards consumers' needs, employees and stakeholders' expectations Porter (1980) considered competitive strategy to be the proactive or defensive actions taken by organizations to create a defendable position in an industry to cope successfully. When investors decide to invest, they consider various factors; among them are desired performance criteria, investment decisions and therefore identifying the factors that influence corporate performance (Slatter, Olson \& Finnegan, 2005). Hambrick (2003) noted that Profitability, Returns and Cash flows are very important factors that affect a company's performance when compared with other companies which will enable the organization to control environmental factor by developing strategies 
suitable for optimal supply and allocation decisions resources (Hambrick, 2003). Parnell (2010) describes strategy as "long-term objectives and appropriate decisions in accordance with the objectives and allocation resources so that the desired goals are achieved." It also states that the strategy is a single project, a comprehensive and integrated of strengths and weaknesses of the organization with the relevant environmental opportunities and threats. Chong, Zey \& Bessler (2010) Posits that the main goal of the organization is to indicate how the company provides the needed financial resources: debt or equity. Business strategy in this study refers to "an integrated set of activities aimed at enhancing the long-term strength and capabilities in relation to competitors. How organization can achieve competitive advantage should be the concern of the management. "Strategies are needed to answer the question of "how can we be in a supportive way to our client's added value? Therefore, this strategy is a complex subject and a different understanding of the strategies that the researchers failed to agree on a basic definition that makes so many people the words of strategy (Conant, Mokwa \& Varadarajan, 1990). Porter model (1980) measure the cost-reduction strategy that includes differentiation strategy, cost management strategy and focus strategy (focused) or typology of Hambrick (2003) which included (WT), farsightedness (exploration), analyst, passive (reactive) and concluded that the strategy analytical, prospective are more performance than defensive strategy of passive (reaction). The first person to be paid specifically to the concept of competitive strategy was Michael Porter. From Porter's vision, to overcome strong opponents in the competition, organization must be equipped with weapons of providing the lowest rates.

\section{Statement of Research Problems}

Customers want the best of goods and services from the companies they purchase commodities from and meeting societal needs comes up with challenges (Blackmore \& Nesbitt, 2013). Consumer requirements and needs keep changing from time to time and that again mounts pressure on firms to seek for competitive strategies to adopt to stay ahead of industry players in the sector where they belong (Sarac, Enton \& Yucel, 2014). Due to the important roles of competitive strategies on corporate performance many countries have instituted different policy support and frameworks to guide the development of organizations (Balsam, Fernado \& Tripathy, 2011). Also, the main elements that mitigate a firm's performance with respect to cost management strategies and focus strategies have not received a lucid in the Nigerian Business environment. This study intends to answer the following research questions to solve the research problem (i) what is the significant effect of cost management strategy on sales turnover? (ii) What is the significant effect of focus strategy on market leadership and market share? (iii) What is the significant effect of competitive strategies on Organizational performance?

\section{Objective of the Study}

i. To examine the significant effect of cost management strategy on sales turnover.

ii. To investigate the significant effect of focus strategies on market leadership and share

iii. To investigate the significant effect of competitive strategies on Organizational performance

\section{Research Hypothesis}

Ho1 cost management strategy has no significant effect on sales turnover.

Ha1 cost management strategy has a significant effect on sales turnover.

Ho2 focus strategy has no significant effect on market leadership and share.

Ha2 focus strategy has a significant effect on market leadership and share

Ho3 competitive strategy has no significant effect Organizational performance.

Ha3 competitive strategy has a significant effect on Organizational performance.

\section{Operationalization of Research Variables}

Examining the efficacy of competitive strategy on Organizational performance has the following constructs:

Dependent construct - corporate performance 
SocioEconomic Challenges, Volume 3, Issue 1, 2019

Independent construct- competitive strategy

The above is mathematically expressed as $\mathrm{Y}=\mathrm{f}(\mathrm{x})$

Where:

$\mathrm{Y}=$ dependent variable

$\mathrm{X}=$ independent variable

$\mathrm{Y}=$ Organizational performance

$\mathrm{X}=$ competitive strategy

Therefore, from this equation, corporate performance would depend on the competitive strategy introduced.

This is expressed as:

Organizational performance $=\mathrm{f}($ competitive strategy $)$

That is $\mathrm{CP}=\mathrm{f}(\mathrm{CS})$

Where $\mathrm{CP}=\mathrm{Y}$ and $\mathrm{CM}=\mathrm{X}$

The $\mathrm{X}$ and $\mathrm{Y}$ are broken down as follows:

$\mathrm{Y}=(\mathrm{Y} 1, \mathrm{y} 2, \mathrm{y} 3$

$\mathrm{Y} 1$ = overall Organizational performance

$\mathrm{Y} 2=$ sales turnover

Y3 = market leadership and share

Similarly, $X=(x 1, x 2, x 3$

Where $\mathrm{X} 1$ = competitive strategy; $\mathrm{X} 2$ = cost management strategy;

$\mathrm{X} 3=$ focus strategy

\section{Literature Review}

Conceptual Review. Porter (1980) theory explains the three strategies that a company can adopt in order to achieve competitive advantages which include the following: (i) Cost management strategy (ii) Product differentiation strategy (iii) Focus Strategy.

The Concept of Cost management strategy. Parnell (2011) noted that the strategy seeks to reduce costs by reducing costs compared with competitors to gain market share. The implementation of this strategy is a priority to maintain stable income and to think about innovation and risk-taking (Porter, 1980). Companies produce or organized products and services at competitive prices but makes sure the quality of products is not reduced. This strategy is employed because customers can find high quality products and lower price in a competitive market (Pertusa et al, 2009). Companies that have adopted the strategy of cost management through the creation and sale of lower production costs than their competitors will be able to increase their market share (Luoma,2015). Ghoshal (2003) pointed that firms can apply different tactics to achieve cost management. These tactics include: (i) use of facilities on a large-scale process improvement (ii) minimize production costs (iii) Total Quality Management (iv) The optimal use of modeling and control of overhead costs in order to remove the adverse deviations. Some of the techniques used in this field include statistical process, control departments, cost management, process reengineering and value chain management (Jennings, Rajaratnam \& Lawrence, 2003).

The Concept of Product differentiation strategy. The implementation of this strategy is to seek the products and services that the industry provides. Products and services have to be distinguished among competitors (Pertusa et al, 2009). This strategy is targeted at customers that are not at the expense of attention, so the above activities can be beneficial to use different strategies to build the product. Product differentiation strategy can reduce the intensity of competition and eradicate threat of product substitution for notice (Olson, Slatter \& Hult, 2005). Successful execution of this strategy requires costly activities such as research and development and great advertisement (Evans \& Green,2000). Differentiators normally charge premium prices for their 
products and services resulting in higher profit margins (Zamani et al, 2013). Higher supplier costs can be paid through these margins and hence the bargaining power of suppliers can be mitigated (Salavou, 2013). Customer loyalty and the need to overcome the uniqueness of differentiated products makes it difficult for new entrants to enter the industry. Brand name and customer loyalty provide immunity to differentiators against the threat from substitute products (Lin, Tsai \& Wu, 2014).

The concept of Focus Strategy. Ghostal (2003) Pointed that Organizations have their share of the downside of the global competitions and the turbulent business environments. Pertusa et al (2009) Posit that core of this strategy is a want to every day getting better at what people do. Customer Service is ever so important to the day-to-day operations of a Council and this strategy outlines people's commitment to the organization. Salavou (2015) Postulates that Customers highest priority is to improve the way managers interact with them which should be the concern of all organization. Today we offer a range of contact options and our customers have the right to expect a consistent experience regardless of the method they choose (Ketchen, 2003). Lin, Tsai \& Wu (2014) Pointed out that recent rapid growth and adoption of new technologies in the digital space is both exciting and daunting for organizations. It means that enterprises must be constantly looking to keep up with community and their needs to be responsive and consistent. Guerard, Langley \& Seidei (2013) states that the strategy commits to four key themes of people, process, technology and measures and is supported by an action plan which outlines the key priorities of actions together with identifying outcomes that will be delivered over the course of the strategy. This strategy must be prepared after extensive consultation with the community - customers, staff, executive management team, Mayor and Councilors. Ongoing feedback is also frequently provided by key stakeholders (ZDesarbo et al, 2005). The Annual Community Survey was a key reference point in preparing the Customer Focus Strategy; but the process also included additional customer surveys, focus groups and workshops with councilors (Datta, Liang \& Musteen, 2009). Focus strategy is designed to provide clear direction for Council to achieve its mission with a commitment to continue to uphold Council's values (Porter, 1980). Parnell, Long \& Lester (2013) emphasized that Customer focus strategy (CSS) is now an accepted way to do business and customers expect to easily interact with Council and have access to accurate information at the times they choose. Customer does not necessarily want to be constrained by the hours of operation of the service. Such interactions include making multiple payments, updating their contact details or checking the status or outcome of a recent request or complaint (Parnell, Long \& Lester, 2015). Salavou (2015) Opined that more effective use of technology to advance in this area is vital and has been identified as a priority. Organization aim to leverage off technology to ensure they meet customer expectations, reduce customer effort and increase internal efficiencies (Luoma, 2015). Creating a central register for a customer name and address record of a single view that can be integrated and appropriately accessed across all services of Council will assist customers to self-serve and improved response times and a better overall customer experience. Porter's strategy in the implementation of the strategy of focusing on a particular kind of product means organization tries to emphasize certain parts of the market or certain groups of purchasers (DowJones et al, 2016). The company will reduce costs and differentiate the product and limit the market to achieve this goal. The characteristics of this strategy can be flexibility in rewarding and intimate relationships with employees providing services to customers in order to increase consumer loyalty, high authority and meeting the needs of customers (Pertusa, Molina \& Claver, 2010).

Organizational performance. Richard et al. (2009) noted that decades of research have being carried out for assessing the performance of Organizations. Results obtained from different studies offer can be categorized into four approaches in relation to the performance criteria which are: Accounting approach: In this approach, the figures contained in the financial statements such as profit, earnings per share, operating cash flows, return on assets and return on equity is used to evaluate the performance (Parnell, 2011). Economic approach: This approach is used in which the economic implications, the performance of an entity with an emphasis on power and profit according to the rate of return on assets and cost of capital rate used is evaluated (Pertusa et al., 2009). Integrated approach: In this approach, a combination of accounting and market information is used to assess performance as Tobin's Q 1 and the ratio of price to earnings (P / E) (Hambrick, 2003). Financial management approach: In accordance with this approach, most of the theories of financial management, capital asset pricing model 1 and concepts of risk and return are being used (Balsam, Fernado \& Tripathy, 2011). The main emphasis of this approach is to determine the excess return per share (Luoma, 2015) 
Empirical Framework of Competitive Strategies. Salavou (2015) studied characteristics of successful strategies of companies in the manufacturing industry and concluded that the combination of assets and how to use them is an important factor in profitability of the company. Pertusa, Molina \& Clover (2010) in a study entitled "Communication strategy, capital structure and function," concluded that liquidity strategy is significantly related to firm performance. If management is looking for performance, management should not waste their time to raise money but instead they should focus on the capital structure of the company's overall performance. Studies in Iran Optical person, Jusoh \& Parnell (2008) for the first time in a study entitled "The impact of cost management strategy on long-term financial performance of top companies listed on Tehran Stock Exchange" came to the conclusion that companies are looking for cost management strategy that can maintain strong financial performance but at the long-run it will not. Bentley, Omar \& Sharp (2013) in a study entitled "The relationship between corporate strategy, capital structure and corporate performance" concluded that the strategy of sales growth with return on equity and return on assets" they found that strategy and liquidity criteria for return on equity, free cash flow per share and return on assets have a positive relationship and capital structure (debt ratio) with the company's free cash flow significantly and positively correlated with return on assets. Lin, Tsai \& Wu (2014) in a research study of Tasyrbkargyry comprehensive quality management on the financial performance of the company (Case study) using this model as one of the tactics of cost management strategy, as a means to measure the efficiency of the company and improve financial performance. Their studies concluded that the TQM model have a positive relationship with financial performance. Jennings, Rajaratnam \& Lawrence (2003) found that cost leadership strategy has significant effect on cost reduction of small and medium enterprises indicating that when firms adopt good cost management strategy, they tend to reduce their cost of operations because the strategy is adopted based on the notion that they are well competent to achieve the purpose which they are meant.

\section{Methodology}

A cross-sectional design was adopted for this study; the population consists of the top and middle level management of Nestle Nigeria Plc. The study population refers to the entirety of employees of Nestle Nigeria Plc. Population for this study was determined using yard's formula. This formula is concerned with applying a normal approximation with a confidence level of $95 \%$ and a limit of tolerance level (error level) of 5\%. (Richard et al, 2009). On this premise, the sample size is determined by $(\mathrm{n}=\ldots \mathrm{N} \quad)$

$$
1+\mathrm{Ne}^{2}
$$

Where

$$
\begin{aligned}
& \mathrm{n}=\text { the sample size } \\
& \mathrm{N}=\text { population } \\
& \mathrm{e}=\text { the limit of tolerance } \\
& \text { Therefore, } \mathrm{n}=\frac{180}{\frac{1+180(0.05)^{2}}{1+180(0.0025)}} \\
& \frac{180}{1+0.45} \\
& \frac{180}{1.45} \\
& =124 \text { respondents }
\end{aligned}
$$

A sample size of one hundred and twenty-four employees out of one hundred and eighty (180) employees was employed for the study. All employees have equal chances of being chosen as part of the sample because 124 questionnaires were administered randomly to the entire employee population. The questionnaire contains both open and closed ended questions to collect data on the subject matter for the study. The questionnaire was divided into two broad categories. The first category is made up of personal data of respondents. This includes; sex, age group, educational qualification, position occupied in the organization and years of work experience. The second category is the body of the questionnaire that includes all questions relevant to this research. It comprises both the negative and positive questions structured on the basis of the constructs of this study i.e. competitive strategy and corporate performance. The likert scale was used to measure opinions, 
where for positive questions (Strongly Agree $=5$, Agree=4, undecided=3, disagree=2, strongly disagree $=1$ ), and for negative questions (Strongly Agree $=5$, Agree $=4$, undecided $=3$, disagree $=2$, strongly disagree $=1$ ). The data was analysed using manual and electronic based methods through the data preparation grid and statistical package for the social sciences, (SPSS). The utilization of structured grids allows specific responses to be located with relative ease and facilitate the identification of emerging patterns (Easterby, Smith, Thorpe \& Jackson (2011). The study adopts the use of statistical tools which include: analysis of variance (ANOVA), correlation efficient and regression analysis in testing hypotheses where applicable. The study made use of Simple linear regression analysis test for hypotheses 1 to 3 since they are measuring significance and effects.

Table 2. Distribution of respondents and response rate

\begin{tabular}{|l|c|c|}
\hline \multicolumn{1}{|c|}{ Respondents Occupation } & Questionnaire administered (sampled) & Percentage of total response (\%) \\
\hline Supervisory & 25 & 25.0 \\
\hline Managerial & 27 & 26.0 \\
\hline Executive & 52 & 49.0 \\
\hline Total & 105 & 100.0 \\
\hline \multicolumn{1}{|c|}{ Gender/Category } & Questionnaire administered (sampled) & Percentage of total response (\%) \\
\hline Male & 75 & 71.4 \\
\hline Female & 30 & 28.6 \\
\hline No of Returned & 105 & 71.4 \\
\hline No of Not Returned & 19 & 28.6 \\
\hline Total no of Questionnaires & 124 & 100 \\
\hline
\end{tabular}

Source: Field Survey 2017.

\section{Data analysis and Hypothesis Testing}

Table 3. The Descriptive statistics of Organizational Learning and Corporate Performance

\begin{tabular}{|l|c|c|}
\hline \multicolumn{1}{|c|}{ Cost Management Strategies \& Sales Turnover } & Total (N) & Mean \\
\hline Overall corporate performance has been improved through the competitive strategies employed & 105 & 4.88 \\
\hline Economics of scale can be achieved through cost reduction strategies & 105 & 3.78 \\
\hline Efficiency in production can be achieved through cost reduction strategies & 105 & 3.89 \\
\hline cost reduction strategies have helped improve sales turnover & 105 & 3.89 \\
\hline improvement in sales turnover has helped to achieve competitive advantage & 105 & 3.76 \\
\hline \multicolumn{1}{|c|}{ Focus Strategy \& Market Leadership/Share } & Total (N) & Mean \\
\hline Focus on particular market segments have helped satisfy customer needs optimally. & 105 & 3.87 \\
\hline The need to expand product reach can lead to creating a market focus & 105 & 3.78 \\
\hline reduction in cost has led to profitability & 105 & 3.77 \\
\hline Benefits sought by customers is used in creating a focus market for a product & 105 & 3.79 \\
\hline focus on market segments have led to market leadership and improved market share & 105 & 3.84 \\
\hline Focus on particular market segments have helped satisfy customer needs optimally. & 105 & 3.69 \\
\hline
\end{tabular}

Source: Field Survey 2017.

Test of Hypotheses and Discussion of Results. Regression analysis was used to measure the effect of the independent variable to the dependent variable of hypothesis 1,2 and 3 and a proper interpretation and analysis technique was used to explain the hypotheses testing.

\section{Hypothesis 1}

$\mathrm{H}_{\mathrm{o} 2}$ cost management strategy has no significant effect on sales turnover.

$\mathrm{H}_{\mathrm{a} 2}$ cost management has a significant effect on sales turnover

Table 4. Model Summary

\begin{tabular}{|c|c|c|c|c|c|c|}
\hline Model & $\mathrm{R}$ & R Square & Adjusted R Square & $\begin{array}{l}\text { Std. Error of the Esti- } \\
\text { mate }\end{array}$ & & \\
\hline 1 & $.990^{\mathrm{a}}$ & .980 & .980 & .15213 & & \\
\hline \multicolumn{7}{|c|}{ Table 5. ANOVA ${ }^{\mathrm{a}}$} \\
\hline Model & & \multirow{2}{*}{\begin{tabular}{|l} 
Sum of Squares \\
16.679
\end{tabular}} & Df & Mean Square & $\mathrm{F}$ & Sig. \\
\hline 1 & Regression & & 1 & 116.679 & 5041.773 & $.000^{\mathrm{b}}$ \\
\hline
\end{tabular}


SocioEconomic Challenges, Volume 3, Issue 1, 2019

ISSN (print) - 2520-6621, ISSN (online) - 2520-6214

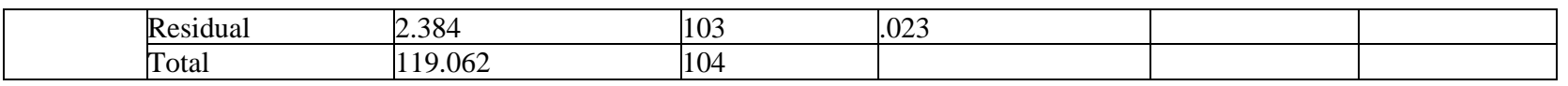

a. Dependent Variable: SALESTURNOVER

b. Predictors: (Constant), MANAGEMENT

Interpretation of Results. The results from the model summary table above revealed that the extent to which the variance in cost leadership can improve sales turnover is $98 \%$ i.e (R square $=0.98)$. The ANOVA table shows the Fcal to be 5041.773at 0.0001 significance level. The implication is that cost management strategy helps to improve sale turnover.

Table 6. Coefficients ${ }^{\mathrm{a}}$

\begin{tabular}{|c|c|c|c|c|c|c|}
\hline \multicolumn{2}{|r|}{ Model } & \multicolumn{2}{|c|}{ Unstandardized Coefficients } & \multirow{2}{*}{\begin{tabular}{|c|}
$\begin{array}{c}\text { Standardized Coeffi- } \\
\text { cients }\end{array}$ \\
Beta \\
\end{tabular}} & \multirow[t]{2}{*}{$\mathrm{T}$} & \multirow[t]{2}{*}{ Sig. } \\
\hline & & B & Std. Error & & & \\
\hline \multirow{2}{*}{1} & (Constant) & -.040 & .064 & & -.621 & .536 \\
\hline & COSTMANAGEMENT & 1.004 & .014 & .990 & 71.005 & .000 \\
\hline
\end{tabular}

a. Dependent Variable: SALESTURNOVER.

The coefficient table above shows the simple model that expresses how cost leadership can lead to improved sales turnover. The model is shown mathematically as follows;

$\mathrm{Y}=\mathrm{a}+\mathrm{bx}$ where $\mathrm{y}$ is sales turnover and $\mathrm{x}$ is cost leadership, $\mathrm{a}$ is a constant factor and $\mathrm{b}$ is the value of coefficient. From this table therefore, COST MANAGEMENT $=-0.040+1.004$ SALES TURNOVER. This means that for every $100 \%$ change in cost of operation, cost management strategy contributed $100 \%$.

Decision. The significance level below 0.01 implies a statistical confidence of above $99 \%$. This implies that cost leadership strategies can lead to improved sales turnover. Thus, the decision would be to reject the null hypothesis $\left(\mathrm{H}_{\mathrm{o}} 2\right)$, and accept the alternative hypothesis $\left(\mathrm{H}_{\mathrm{a}} 2\right)$.

\section{Hypothesis 2}

$\mathrm{H}_{\mathrm{o} 2}$ focus strategy has no significant effect on market leadership and share.

$\mathrm{H}_{\mathrm{a} 2}$ focus strategy has a significant effect on market leadership and share.

Table 7. Model Summary

\begin{tabular}{|l|l|l|l|l|}
\hline Model & R & R Square & Adjusted R Square & Std. Error of the Estimate \\
\hline 1 & $.972^{\mathrm{a}}$ & .944 & .943 & .25140 \\
\hline
\end{tabular}

Table 8. ANOVA $^{\mathrm{a}}$

\begin{tabular}{|l|l|l|l|l|l|l|}
\hline Model & Sum of Squares & df & Mean Square & F & Sig. \\
\hline \multirow{3}{*}{1} & Regression & 109.369 & 1 & 109.369 & 1730.433 & $.000^{\mathrm{b}}$ \\
\cline { 2 - 8 } & Residual & 6.510 & 103 & .063 & & \\
\cline { 2 - 8 } & Total & 115.879 & 104 & & & \\
\hline
\end{tabular}

a. Dependent Variable: MARKETLEADERSHIP.

b. Predictors: (Constant), MARKETFOCUS.

\section{Interpretation of Results}

The results from the model summary table above revealed that the extent to which the variance in market focus strategy can lead to market leadership and share is $94.4 \%$ i.e ( $\mathrm{R}$ square $=0.944$ ). The ANOVA table shows the Fcal to be 1730.433at 0.0001 significance level. The implication is that market focus strategy leads to market leadership and shar

Table 9. Coefficients ${ }^{\mathrm{a}}$

\begin{tabular}{|c|c|c|c|c|c|c|}
\hline \multicolumn{2}{|r|}{ Model } & \multicolumn{2}{|c|}{ Unstandardized Coefficients } & \multirow{2}{*}{\begin{tabular}{|c|}
$\begin{array}{c}\text { Standardized Coeffi- } \\
\text { cients }\end{array}$ \\
Beta \\
\end{tabular}} & \multirow[t]{2}{*}{$\mathrm{t}$} & \multirow[t]{2}{*}{ Sig. } \\
\hline & & B & Std. Error & & & \\
\hline \multirow{2}{*}{1} & (Constant) & .178 & .104 & & 1.704 & .091 \\
\hline & MARKETFOCUS & .966 & .023 & .972 & 41.598 & .000 \\
\hline
\end{tabular}


The coefficient table above shows the simple model that expresses how market focus can lead to improved market leadership and share. The model is shown mathematically as follows; $Y=a+b x$ where $y$ is market leadership and $\mathrm{x}$ is market focus, $\mathrm{a}$ is a constant factor and $\mathrm{b}$ is the value of coefficient. From this table therefore, MARKET FOCUS $=0.178+0.966$ MARKET LEADERSHIP. This means that for every $100 \%$ change in market leadership, market focus contributed $96.6 \%$.

\section{Decision}

The significance level below 0.01 implies a statistical confidence of above $99 \%$. This implies that market focus strategies can lead to improved market leadership and share. Thus, the decision would be to reject the null hypothesis $\left(\mathrm{H}_{\mathrm{o}} 3\right)$, and accept the alternative hypothesis $\left(\mathrm{H}_{\mathrm{a}} 3\right)$.

\section{Hypothesis 3}

$\mathrm{H}_{03} \quad$ competitive strategy has no significant effect on overall Organizational performance.

$\mathrm{H}_{\mathrm{a} 3} \quad$ competitive strategy has a significant effect on overall Organizational performance

Table 10. Model Summary

\begin{tabular}{|l|l|l|l|l|}
\hline Model & R & R Square & Adjusted R Square & Std. Error of the Estimate \\
\hline 1 & $.990^{\mathrm{a}}$ & .981 & .980 & .14614 \\
\hline
\end{tabular}

a. Predictors: (Constant), OVERALLCOMPETITIVESTRATEGIES.

Table 11. ANOVA ${ }^{\mathrm{a}}$

\begin{tabular}{|c|c|c|c|c|c|c|}
\hline \multicolumn{2}{|c|}{ Model } & Sum of Squares & df & Mean Square & F & Sig. \\
\hline \multirow{4}{*}{1} & Regression & 111.527 & 1 & 111.527 & 5221.932 & $.000^{\mathrm{b}}$ \\
\cline { 2 - 8 } & Residual & 2.200 & 103 & .021 & & \\
\cline { 2 - 8 } & Total & 113.726 & 104 & & & \\
\hline
\end{tabular}

a. Dependent Variable: OVERALLORGANIZATIONALPERFORMANCE

b. Predictors: (Constant), COMPETITIVESTRATEGIES

\section{Interpretation of Results}

The results from the model summary table above revealed that the extent to which the variance in competitive strategies can improve corporate performance is $98.1 \%$ i.e $(\mathrm{R}$ square $=0.981)$. The ANOVA table shows the Fcal to be 5221.932at 0.0001 significance level. The implication is that competitive strategies help to improve corporate performance.

Table 12. Coefficients ${ }^{\mathrm{a}}$

\begin{tabular}{|c|c|c|c|c|c|c|}
\hline \multicolumn{2}{|c|}{ Model } & \multicolumn{2}{|c|}{ Unstandardized Coefficients } & \multirow{2}{*}{$\begin{array}{c}\text { Standardized Coef- } \\
\text { ficients }\end{array}$} & \multirow{2}{*}{ Sig. } \\
\cline { 3 - 7 } \multicolumn{2}{|c|}{} & B & Std. Error & Beta & & \\
\hline \multirow{2}{*}{1} & (Constant) & .060 & .061 & & .970 & .334 \\
\cline { 2 - 7 } & COMPETITIVESTRATEGIES & .987 & .014 & .990 & 72.263 & .000 \\
\hline
\end{tabular}

a. Dependent Variable: OVERALLORGANIZATIONALPERFORMANCE

The coefficient table above shows the simple model that expresses how competitive strategies can improve corporate performance. The model is shown mathematically as follows; $\mathrm{Y}=\mathrm{a}+\mathrm{bx}$ where $\mathrm{y}$ is corporate performance and $\mathrm{x}$ is competitive strategies, $\mathrm{a}$ is a constant factor and $\mathrm{b}$ is the value of coefficient. From this table therefore, COMPETITIVE STRATEGIES $=0.060+0.987$ OVERALL CORPORATE PERFORMANCE. This means that for every $100 \%$ change in corporate performance, competitive strategies contributed $98.7 \%$.

\section{Decision}

The significance level below 0.01 implies a statistical confidence of above 99\%. This implies that competitive strategies can lead to improved overall corporate performance. Thus, the decision would be to reject the null hypothesis $\left(\mathrm{H}_{0} 4\right)$, and accept the alternative hypothesis $\left(\mathrm{H}_{\mathrm{a}} 4\right)$.

\section{Conclusion}


The importance of organizations in today's global world cannot be over-emphasized. Businesses all over the world go as far as possible to acquire competitive strategies that help them improve Organizational performance while also creating sustainable competitive advantage over competitors. This study is an important study that helps to evaluate the efficacy of competitive strategies on Organizational performance. The study found that for organizations to remain competitive and relatively relevant in the fierce economy where stiff competition abounds, they must be able to discover and create distinctive competencies that must be in line with competitive strategies that help improve overall Organizational performance while consequently leading to sustained competitive advantage over competitors. This study provides information for organizations to know the essence of formulating and implementing competitive strategies that help remain competitively relevant in their various sectors. The study amongst other things would help organization create a scorecard on which performance can be measured in relation to variables used in the research study. Since the study will assist new organizations to enter into industry, it will also be an opportunity for existing organizations to be abreast of strategies that helps them standout in their industry. The conclusion however is that competitive strategy has a positive impact on Organizational performance. The extant literature shows that this conclusion is valid in several sectors and countries and has been applied systematically. This study brings together two streams of research: competitive strategies and Organizational performance in relation to the Nestle Nigeria plc. More importantly it also identified the importance and extent of moderating variables of competitive strategies as it affects Organizational performance in terms of cost reduction, sales turnover and market leadership and share.

\section{Recommendation}

$>$ Since it has been reflected in this study that cost management strategies can be carried out without high cost. Organizations should endeavour to provide more frameworks for carrying out research and development that will help create an edge for the organization over its competitors while avoiding financial crisis.

$>$ It is recommended that organizations should seek ways of creating cost leadership in their industry while improving quality as this would ultimately lead to improved sales turnover.

$>$ Organizations should be willing to consider every aspect of the broad market before focusing on a particular focus market. The finding in the study has shown that the adoption of appropriate market focus strategies affects market leadership and share.

$>$ Organizations should consistently seek ways of utilizing the competitive strategies at their disposal as it helps improve Organizational performance and ultimately lead to a sustained competitive advantage over competitors.

\section{References}

1. Dow Jones -Irwin. Anwar, J. and S. Hasnu (2016). Strategy-performance relationship: A scoring method framework for typological research. International Journal of Information, Business and Management, $8(2), 19-35$.

2. Balsam, S., G. D. Fernando and A. Tripathy (2011). The impact of firm strategy on performance measures used in executive compensation. Journal of Business Research, 64(2), 187-193. http://dx.doi.org/10.1016/j.jbusres.2010.01.006 .

3. Bentley, K. A., T. C. Omer and N. Y. Sharp (2013). Business strategy, financial reporting irregularities, and audit effort. Contemporary Accounting Research, 30(2), 780-817. http://dx.doi.org/10.1111/j.1911$\underline{3846.2012 .01174 . \mathrm{x}}$

4. Blackmore, K. and K. Nesbitt (2013). Verifying the Miles and Snow strategy types in Australian smalland medium-size enterprises. Australian Journal of Management, 38(1), 171-190. http://dx.doi.org/10.1177/0312896212444692

5. Chong, H., M. Zey and D. A. Bessler (2010). On corporate structure, strategy, and performance: A study with directed acyclic graphs and PC algorithm. Managerial and Decision Economics, 31(1), 47-62. http://dx.doi.org/10.1002/mde.1475 
6. Conant, J. S., M. P. Mokwa and P. R. Varadarajan (1990). Strategic types, distinctive marketing competencies and organizational performance: A multiple measures-based study. Strategic Management Journal, 11(5), 365-383. http://dx.doi.org/10.1002/smj.4250110504

7. Datta, D. K., X. Liang and M. Musteen (2009). Strategic orientation and the choice of foreign market entry mode: An empirical examination. Management International Review, 49(3), 269-290. http://dx.doi.org/10.1007/S11575-009-0143-.

8. Evans, J. D. and C. L. Green (2000). Marketing strategy, constituent influence, and resource allocation: An application of the Miles and Snow typology to closely held firms in Chapter 11 Bankruptcy. Journal of Business Research, 50(2), 225-231. http://dx.doi.org/10.1016/S0148-2963(99)00036-3 ANWAR et al.: Business Strategy and Organizational Performance 119.

9. Easterby-Smith, M., Thorpe, R.,\& Jackson, P.R. (2011). Management research (3 rd Edition). London: SAGE Publications.

10. Ghoshal, S. (2003). Miles and Snow: Enduring insights for managers. The Academy of Management Executive, 17(4), 109-114. http://www.jstor.org/stable/4166012.

11. Guérard, S., A. Langley and D. Seidi (2013). Re thinking the concept of performance in strategy research: Towards a performativity perspective. Management (France), 16(5), 566-578. http://dx.doi.org/10.3917/mana.165.0566.

12. Hambrick, D. C. (1981). Strategic awareness within top management teams. Strategic Management Journal, 2(3), 263-279. http://dx.doi.org/10.1002/smj.4250020305.

13. Hambrick, D. C. (2003), On the staying power of defenders, analyzers, and prospectors. The Academy of Management Executive, 17(4), 115-118. http://www.jstor.org/stable/4166013.

14. Jennings, D. F., D. Rajaratnam and F. B. Lawrence (2003). Strategy-performance relationships in service firms : A test for equifinality. Journal of Managerial Issues, 15(2), 208-220. http://www.jstor.org/stable/40604426.

15. Jusoh, R. and J. A. Parnell (2008). Competitive strategy and performance measurement in the Malaysian context: An exploratory study. Management Decision, 46(1), 5-31. http://dx.doi.org/10.1108/00251740810846716.

16. Ketchen, D. J. (2003). Introduction: Raymond E. Miles and Charles C. Snow's organizational strategy, structure, and process. The Academy of Management Executive, 17(4), 94-96. http://www.jstor.org/stable/4166009.

17. Lin, C., H. L. Tsai and J. C. Wu (2014). Collaboration strategy decision-making using the Miles and Snow typology. Journal of Business Research, 67(9), 1979-1990. http://dx.doi.org/10.1016/j.jbusres.2013.10.013 120.

18. Luoma, M. A. (2015). Revisiting the strategy-performance linkage: An application of an empirically derived typology of strategy content areas. Management Decision, 53(5), 1083-1106. http://dx.doi.org/10.1108/MD-10-2014-0593.

19. Olson, E. M., S. F. Slater and G. T. M. Hult (2005). The performance implications of fit among business strategy, marketing organization structure, and strategic behavior. Journal of Marketing, 69(3), 49-65. http://dx.doi.org/10.1509/jmkg.69.3.49.66362.

20. Parnell, J. A. (2010), Strategic clarity, business strategy and performance. Journal of Strategy and Management, 3(4), 304-324. http://dx.doi.org/10.1108/17554251011092683.

21. Parnell, J. A. (2011). Strategic capabilities, competitive strategy, and performance among retailers in Argentina, Peru and the United States. Management Decision, 49(1), 139-155. http://dx.doi.org/10.1108/00251741111094482.

22. Parnell, J. A., M. A. Koseoglu, Z. Long and J. E. Spillan (2013). Competitive strategy, uncertainty, and performance: An exploratory assessment of China and Turkey. Journal of Transnational Management, 17, 91-117. http://dx.doi.org/10.1080/15475778.2012.676957.

23. Parnell, J. A., Z. Long and D. Lester (2015). Competitive strategy, capabilities and uncertainty in small and medium sized enterprises (SMEs) in China and the United States. Management Decision, 53(2), 402431. http://dx.doi.org/10.1108/MD-04-2014-0222

24. Pertusa-Ortega, E. M., J. F. Molina-Azorín and E. Claver-Cortés (2009). Competitive strategies and firm performance: A comparative analysis of pure, hybrid and 'stuck-in-the-middle' strategies in Spanish 
firms. British Journal of ANWAR et al.: Business Strategy and Organizational Performance 121 Management, 20, 508-523. http://dx.doi.org/10.1111/j.1467-8551.2008.00597.x.

25. Pertusa-Ortega, E. M., J. F. Molina-Azorín and E. Claver-Cortés (2010). Competitive strategy, structure and firm performance: A comparison of the resource-based view and the contingency approach. Management Decision, 48(8), 1282-1303. http://dx.doi.org/10.1108/00251741011076799.

26. Porter, M. E. (1980). Competitive Strategy. New York: The Free Press.

27. Porter, M. E. (1985). Competitive Advantage. New York: The Free Press

28. Richard, P. J., T. M. Devinney, G. S. Yip and G. Johnson (2009). Measuring organizational performance: Towards methodological best practice. Journal of Management, 35(3), 718-804 http://dx.doi.org/10.1177/0149206308330560.

29. Salavou, H. E. (2013). Hybrid strategies in Greece: A pleasant surprise. European Business Review, Volume 25(3), 301-314. http://dx.doi.org/10.1108/09555341311314834.

30. Salavou, H. E. (2015). Competitive strategies and their shift to the future. European Business Review, 27(1), 80-99. http://dx.doi.org/10.1108/EBR-04-2013-0073.

31. Saraç, M., Y. Ertan and E. Yücel (2014). How do business strategies predict firm performance? An investigation on Borsa Istanbul 100 Index. The Journal of Accounting and Finance, 61, 121-134.

32. Slater, S. F., E. M. Olson and C. Finnegan (2011). Business strategy, marketing organization culture, and performance. Marketing Letters, 22(3), 227-242. http://dx.doi.org/10.1007/s11002-010-9122-1

33. Zamani, S., J. A. Parnell, H. Labbaf and N. O'Regan (2013). Strategic change and decision making in an emerging nation: An exploratory assessment of Iranian manufacturing firms. Strategic Change, 22(5-6), 355-370. http://dx.doi.org/10.1002/jsc.1945.

34. ZDeSarbo, W. S., C. A. Di Benedetto, M. Song and I. Sinha (2005). Revisiting the Miles and Snow strategic framework: Uncovering interrelationships between strategic types, capabilities, environmental uncertainty, and firm performance. Strategic Management Journal, 26(1), 47-74. http://dx.doi.org/10.1002/smj.431. 